Superalloys 2012: 12 $^{\text {th }}$ International Symposium on Superalloys

\title{
ALLOYING EFFECTS ON HEAT-TREATED MICROSTRUCTURE IN CO-AL-W-BASE SUPERALLOYS AT $1300^{\circ} \mathrm{C}$ AND $900^{\circ} \mathrm{C}$
}

\author{
Fei Xue ${ }^{1}$, Meiling Wang ${ }^{2}$, and Qiang Feng, ${ }^{1,2}$ \\ ${ }^{1}$ State Key Laboratory for Advanced Metals and Materials \\ University of Science and Technology Beijing, Beijing, 100083, China \\ ${ }^{2}$ National Center for Materials Service Safety \\ University of Science and Technology Beijing, Beijing, 100083, China
}

Keywords: Co-base superalloys, alloying elements, heat treatment, phase equilibria, secondary phase

\begin{abstract}
Two levels of non-refractory $(\mathrm{V}$ and $\mathrm{Ti}$ ) and refractory $(\mathrm{Mo}, \mathrm{Nb}$ and $\mathrm{Ta}$ ) alloying elements were added to Co-9Al-10W ternary alloy (at.\%, baseline alloy) in order to investigate alloying effects on phase equilibria, microstructural features of $\gamma^{\prime}$ phase and secondary phases at $1300^{\circ} \mathrm{C}$ and $900^{\circ} \mathrm{C}$, respectively. It is suggested that refractory alloying additions promoted the precipitation of the $\mu$ phase at $1300^{\circ} \mathrm{C}$. The phase equilibria changed from $\gamma$ single-phase region in the baseline alloy to $\gamma+\mu$ two-phase region in quaternary alloys containing high levels of refractory alloying elements (4 at.\%) at $1300^{\circ} \mathrm{C}$. The $\mu$ phase was enriched in $\mathrm{W}, \mathrm{Mo}, \mathrm{Nb}$ and $\mathrm{Ta}$, but depleted in $\mathrm{Al}, \mathrm{V}$ and Ti. For quaternary alloys with low levels of alloying additions (2 at.\%), the $\gamma / \gamma^{\prime}$ two-phase microstructure was observed after aging treatment at $900^{\circ} \mathrm{C}$ for $50 \mathrm{~h}$ and $300 \mathrm{~h}$, but small amounts of the plate-like $\mathrm{DO}_{19}$ phase precipitated in the matrix of $2 \mathrm{Mo}$ and $2 \mathrm{Nb}$ alloys. The volume fractions of the $\gamma$ ' phase were at very high level in the range of $74 \%$ to $83 \%$ in all these experimental alloys. Compared with the baseline alloy, alloying additions did not show the strong effect on $\gamma^{\prime}$ morphology, which remained cuboidal after long term aging except Mo addition. For quaternary alloys with high levels of alloying additions after aging at $900^{\circ} \mathrm{C}$, the $\mathrm{DO}_{19}$ phase precipitated in addition to $\gamma$ and $\gamma^{\prime}$ phases, as well as the blocky $\mu$ phase inherited from the precipitation at $1300^{\circ} \mathrm{C}$. There were two types of the $\mathrm{DO}_{19}$ phase: one was plate-like and precipitated in the matrix; the other was blocky and transformed from the previous $\mu$ phase. Again, refractory alloying additions (Mo, Nb and $\mathrm{Ta}$ ) promoted phase transformation for both types of the $\mathrm{DO}_{19}$ phase. The current study is helpful to understand phase equilibria and microstructure in Co-Al-W-base alloys and further develop multi-component $\gamma^{\prime}$-strengthened Co-base superalloys.
\end{abstract}

\section{Introduction}

The successive development of superalloys has been motivated by the demand to enhance the performance and efficiency of gas turbines in aerospace and power-generation industries. Co-base superalloys exhibit superior corrosion, oxidation and wear resistance, but lack in effective precipitation strengthening in comparison with $\gamma^{\prime}$-strengthened Ni-base superalloys [1]. Therefore, they exhibit lower high-temperature capability and relatively limited application in gas turbine industries. In recent years, $\gamma^{\prime}-\mathrm{Co}_{3}(\mathrm{Al}, \mathrm{W})$ strengthened $\mathrm{Co}-\mathrm{Al}-\mathrm{W}$-base alloys with higher strength than that of traditional Co- and Ni-base superalloys were reported, and served as the possible candidate for high-temperature structure materials [2-4].

However, according to previous studies, high-temperature strength of this class of Co-base alloys is still significantly lower than that of advanced Ni-base single crystal superalloys, primarily due to lower $\gamma^{\prime}$ solvus temperature [3, 4]. In order to further develop this new class of superalloys as promising structural materials, alloying effects on Co-Al-W-base superalloys were investigated in an attempt to understand and achieve desired high-temperature performance. Ta addition was reported to effectively promote $\gamma^{\prime}$ solvus temperature and correspondingly enhance high-temperature strength of Co-Al-W-base alloys [2-5]. Other studies indicated that $\mathrm{V}, \mathrm{Ti}, \mathrm{Nb}, \mathrm{Mo}, \mathrm{Cr}$ and $\mathrm{Ni}$ additions also stabilized $\gamma^{\prime}$ phase with higher $\gamma^{\prime}$ solvus temperature, but Re and Fe additions showed negative effect on $\gamma^{\prime}$ solvus temperature [2-4, 6-8]. In addition to $\gamma^{\prime}$ phase stability, the $\gamma^{\prime}$ volume fraction and $\gamma / \gamma^{\prime}$ lattice misfit, which is correlated with $\gamma^{\prime}$ morphology, have considerable influence on creep resistance of Ni-base superalloys [1, 9]. It was reported that the $\gamma^{\prime}$ volume fraction was increased by Ti, $\mathrm{Nb}$, Ta and $\mathrm{V}$ additions, but decreased with the additions of $\mathrm{Ni}, \mathrm{Fe}, \mathrm{Cr}, \mathrm{Mo}$, and $\mathrm{Re}$ in Co-Al-W-base alloys [6-8]. The $\gamma^{\prime}$ morphology changed to spherical and cuboidal with Mo and Ta additions, respectively [2, 10]. However, these studies were quite limited and the effects of alloying additions on $\gamma^{\prime}$ volume fraction and morphology under long term heat treatment were rarely reported.

Phase equilibria and microstructural stability at high temperature are quite essential for superalloys, since deleterious phases such as topological-close-packed (TCP) phases may precipitate after long term thermal exposure. According to Co-rich corner of $\mathrm{Co}-\mathrm{Al}$, $\mathrm{Co}-\mathrm{W}$ and Co-Al-W phase diagrams, CoAl-base $\beta$ phase, $\mathrm{Co}_{7} \mathrm{~W}_{6}$-base $\mu$ phase and $\mathrm{Co}_{3} \mathrm{~W}$-base $\mathrm{DO}_{19}$ phase may exist in Co-Al-W-base alloys at high temperature, especially the $\gamma / \gamma^{\prime}$ two-phase region was too narrow $[2,11]$. The basic crystallography of these phases is listed in Table I. Previous reports indicated that these secondary phases were presented in alloys with relatively high content of $\mathrm{W}$, Re and Mo, and they may probably serve as detrimental precipitates due to their plate-like morphology and refractory-rich compositions [4, 10, 12-14]. On the other hand, alloying elements that enlarge the $\gamma / \gamma^{\prime}$ two-phase region are greatly required to improve microstructural stability, but only Ni addition exhibited positive influence to our current knowledge [7]. Thus, one of these challenges is to understand alloying effect on phase equilibria for desired microstructural stability. To date, there have been limited systematic studies of the influence of alloying additions on phase equilibria and microstructure stability due to initial development stage of Co-Al-W-base superalloys.

In the current study, Co-Al-W-base quaternary alloys containing different alloying elements were investigated. Of particular interest was alloying effects on phase equilibria, $\gamma^{\prime}$ phase morphology, precipitation of secondary phases and microstructural evolution during aging treatment, as well as transformation temperatures. 
Table I. Basic crystallography of $\beta, \mu$ and $\mathrm{DO}_{19}$ phases.

\begin{tabular}{|c|c|c|c|c|c|c|}
\hline Phase & $\begin{array}{c}\text { Strukturbericht } \\
\text { symbol }\end{array}$ & Prototype & $\begin{array}{c}\text { Pearson } \\
\text { symbol }\end{array}$ & Space group & $\begin{array}{c}\text { Space group } \\
\text { number }\end{array}$ & Example \\
\hline$\beta$ & $\mathrm{B} 2$ & $\mathrm{ClCs}$ & $\mathrm{cP} 2$ & $\mathrm{Pm} \overline{3} \mathrm{~m}$ & 221 & $\mathrm{CoAl}$ \\
\hline$\mu$ & $\mathrm{D}_{5}$ & $\mathrm{Fe}_{7} \mathrm{~W}_{6}$ & $\mathrm{hR} 13$ & $\mathrm{R} 3 \bar{m}$ & 166 & $\mathrm{Co}_{7} \mathrm{~W}_{6}$ \\
\hline $\mathrm{DO}_{19}$ & $\mathrm{DO}_{19}$ & $\mathrm{Ni}_{3} \mathrm{Sn}$ & $\mathrm{hP} 8$ & $\mathrm{P}_{3} / \mathrm{mmc}$ & 194 & $\mathrm{Co}_{3} \mathrm{~W}$ \\
\hline
\end{tabular}

\section{Experimental Procedures}

The nominal compositions and abbreviated names of experimental alloys are listed in Table II. Co-9Al-10W ternary alloy serves as the baseline alloy due to its desired microstructural stability and higher microhardness according to our previous study [13]. Two levels of non-refractory ( $\mathrm{V}$ and $\mathrm{Ti}$ ) and refractory (Mo, $\mathrm{Nb}$ and $\mathrm{Ta}$ ) alloying elements were added to the baseline alloy. Ti, Ta and V, mainly $\gamma^{\prime}$-forming elements, as well as Mo and $\mathrm{Nb}$ (including Ta), refractory alloying elements referring to their strengthening effects, were selected in the current study. 2 and 4 at.\% were named as low and high levels of alloying additions to explore possible difference of their alloying effects, respectively.

Table II. Nominal compositions of experimental Co-Al-W-base superalloys, at.\%.

\begin{tabular}{|c|c|c|c|c|c|c|c|c|}
\hline $\begin{array}{c}\text { Alloy } \\
\text { name }\end{array}$ & $\mathrm{Co}$ & $\mathrm{Al}$ & $\mathrm{W}$ & $\mathrm{V}$ & $\mathrm{Ti}$ & $\mathrm{Mo}$ & $\mathrm{Nb}$ & $\mathrm{Ta}$ \\
\hline Baseline & bal. & 9 & 10 & - & - & - & - & - \\
\hline $2 \mathrm{~V}$ & bal. & 9 & 10 & 2 & - & - & - & - \\
\hline $4 \mathrm{~V}$ & bal. & 9 & 10 & 4 & - & - & - & - \\
\hline $2 \mathrm{Ti}$ & bal. & 9 & 10 & - & 2 & - & - & - \\
\hline $4 \mathrm{Ti}$ & bal. & 9 & 10 & - & 4 & - & - & - \\
\hline $2 \mathrm{Mo}$ & bal. & 9 & 10 & - & - & 2 & - & - \\
\hline $4 \mathrm{Mo}$ & bal. & 9 & 10 & - & - & 4 & - & - \\
\hline $2 \mathrm{Nb}$ & bal. & 9 & 10 & - & - & - & 2 & - \\
\hline 4Nb & bal. & 9 & 10 & - & - & - & 4 & - \\
\hline $2 \mathrm{Ta}$ & bal. & 9 & 10 & - & - & - & - & 2 \\
\hline 4Ta & bal. & 9 & 10 & - & - & - & - & 4 \\
\hline
\end{tabular}

Experimental alloys were made from high-purity metals in an arc melting furnace under an argon atmosphere. Alloy buttons with about $20 \mathrm{~g}$ in weight were alternately melted more than 10 times in order to achieve homogeneous compositions. After arc melting, alloy samples, which were placed in an argon-pressurized quartz tube, were homogenized at $1300^{\circ} \mathrm{C}$ for $168 \mathrm{~h}$ ( $8 \mathrm{~h}$ and $12 \mathrm{~h}$ for $2 \mathrm{Mo}$ and $4 \mathrm{Mo}$ alloys, respectively), and then aged at $900^{\circ} \mathrm{C}$ for $50 \sim 300 \mathrm{~h}$ to investigate the influence of alloying elements on microstructural evolution. Heat treatments were followed by water quenching, except for the baseline alloy by air cooling.

Microstructural observation of as-cast and heat-treated samples was conducted with an optical microscope and a ZEISS SUPRA 55 field-emission scanning electron microscope (FESEM) in secondary electron (SE) and back-scattered electron (BSE) imaging modes. Differential scanning calorimetry (DSC) was performed using a NETZSCH STA 449C thermal analyzer under high purity argon flow. The transformation temperatures of experimental alloys were determined based on the DSC heating curves with a heating rate of $10^{\circ} \mathrm{C} / \mathrm{min}$, including $\gamma^{\prime}$ solvus, solidus and liquidus temperatures. The $\gamma^{\prime}$ volume fraction was measured by the standard point count method. The volume fraction of secondary phases in heat-treated alloys was measured by the Image-Pro 6.0 software in BSE images. The semi-quantitative and quantitative concentrations of secondary phases were determined by an energy dispersive spectroscope (EDS) attached to the FESEM and a JEOL JXA-8800R electron probe microanalyzer (EPMA), respectively. In order to identify these secondary phases, X-ray diffraction (XRD) patterns were obtained from bulk samples by a Rigaku D/max-RB12 diffractometer using $\mathrm{Cu} \mathrm{K} \alpha$ radiation.

\section{Results}

\section{Low levels of alloying additions}

The microstructure of ternary (baseline alloy) and quaternary alloys with low levels of alloying additions was examined by using the BSE mode via SEM after solidification and heat treatment at $1300^{\circ} \mathrm{C}$. Figures 1 (a1) (f1) show the typical microstructure of these experimental alloys after solidification, presenting the dendritic structure in the as-cast condition. As exhibited in Figure 1(a1), no eutectic structure was formed in the interdendritic regions of the baseline alloy. There was no apparent change in the interdendritic regions by $2 \mathrm{~V}$ addition (Figure 1(b1)), whereas $2 \mathrm{Ti}$ addition promoted the formation of small amounts of eutectic pools with dark-contrast in the interdendritic regions (Figure 1(c1)). For quaternary alloys with refractory alloying elements, trace amounts of bright-contrast eutectic structure were observed in the interdendritic regions by 2Mo addition (Figure 1(d1)), and relatively large amounts of the eutectic structure with the same contrast existed in 2Nb and 2Ta alloys, exhibited in Figures 1(e1) and (f1). The dark-contrast phase in 2Ti alloy contained high levels of $\mathrm{Al}$ and Ti, presumably $\beta$ phase, and the bright-contrast phases in alloys with refractory alloying additions were enriched in W, Mo, $\mathrm{Nb}$ and Ta, suggesting $\mu$ phase. XRD did not identify these eutectic structures because of their limited amounts.

Figures 1 (a2) (f2) show typical microstructure of these experimental alloys after heat treatment at $1300^{\circ} \mathrm{C}$ for $168 \mathrm{~h}$, exhibiting that the dendritic structure disappeared and the eutectic structure was completely dissolved into the $\gamma$ matrix. Trace amounts of bright-contrast precipitates $\left(\mathrm{V}_{f} \sim 0.05 \%\right)$ were found to exist in the $\gamma$ matrix of the baseline alloy (Figure 1(a2)), and no secondary phase was observed in the $2 \mathrm{~V}$ and $2 \mathrm{Ti}$ alloys, shown in Figures 1(b2) (c2). Figures 1(d2) (f2) exhibit that 2Mo, 2Nb and 2Ta additions slightly increased the volume fraction of bright-contrast precipitates $\left(\mathrm{V}_{f}<2 \%\right)$ in the matrix. The composition analyses using SEM-EDS indicated that these bright-contrast phases were enriched in refractory alloying elements (W, Mo, $\mathrm{Nb}$ and $\mathrm{Ta}$ ) with the depleted content of $\mathrm{Al}$, and therefore considered as $\mu$ precipitates. According to microstructural observation and the narrow $\gamma / \gamma^{\prime}$ two-phase region in most Co-Al-W-base alloys, these experimental alloys in the current study were regarded as $\gamma$ single-phase alloys with small amounts of the $\mu$ phase after heat treatment at $1300^{\circ} \mathrm{C}$, in order to investigate the influence of alloying elements on $\gamma / \gamma^{\prime}$ two-phase microstructure after the following aging treatment at $900^{\circ} \mathrm{C}$ was employed.

The $\gamma / \gamma^{\prime}$ two-phase microstructure was achieved in these experimental alloys after heat treatment at $900^{\circ} \mathrm{C}$. In addition to $\gamma / \gamma$ phases, the $\mu$ phase, inheriting from the precipitation at $1300^{\circ} \mathrm{C}$, 
As-cast

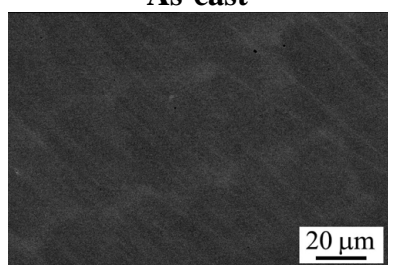

(a1)

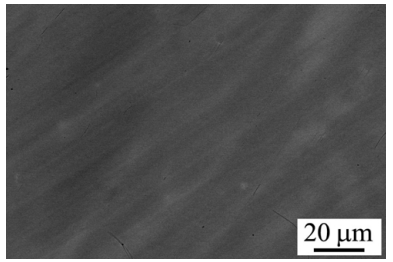

(b1)

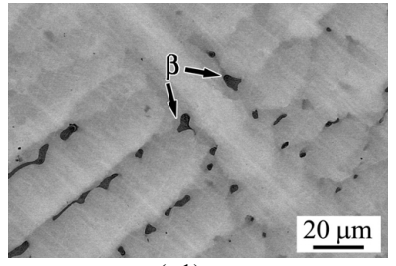

(c1)

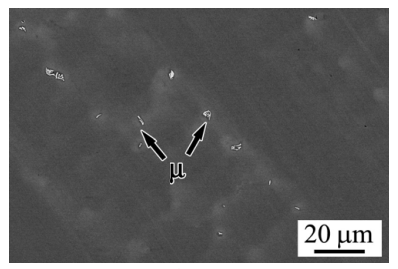

(d1)

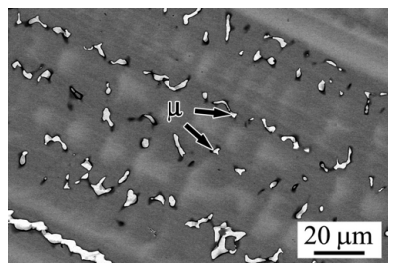

(e1)

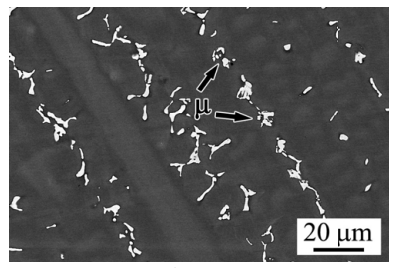

(f1)

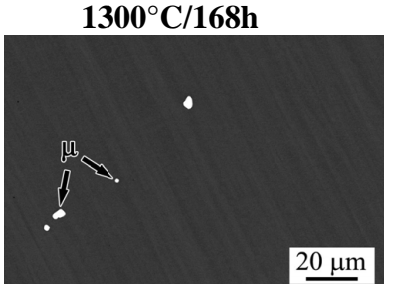

(a2)

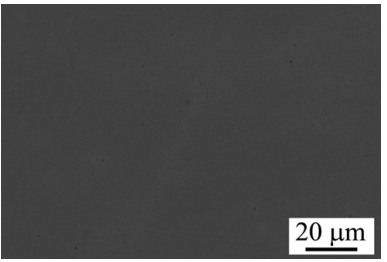

(b2)

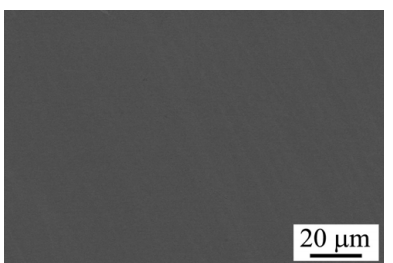

(c2)

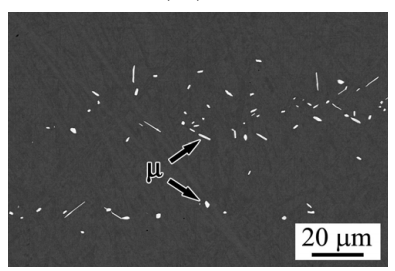

(d2)

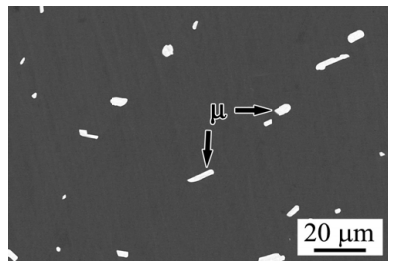

(e2)

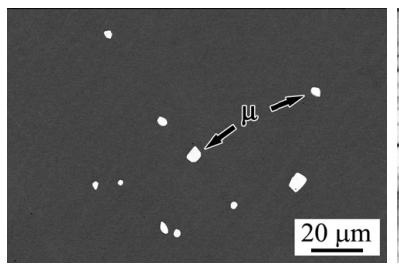

(f2) $900^{\circ} \mathrm{C} / 50 \mathrm{~h}$

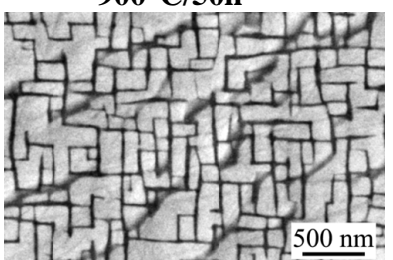

(a3)

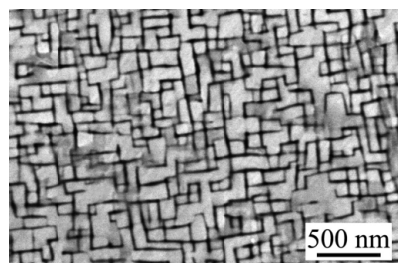

(b3)

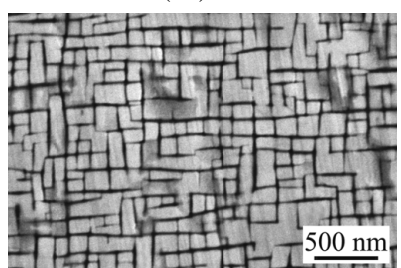

(c3)

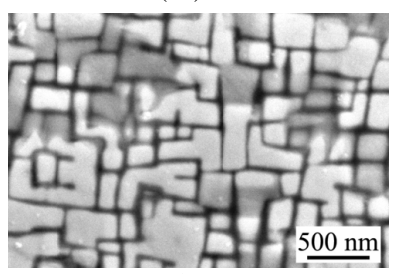

(d3)

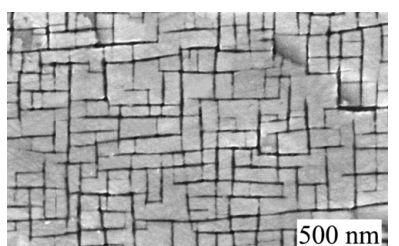

(e3)

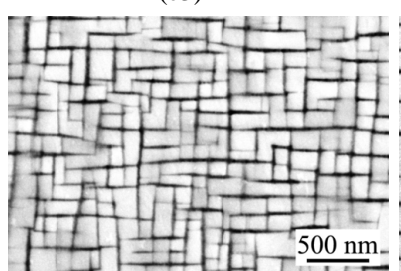

(f3)

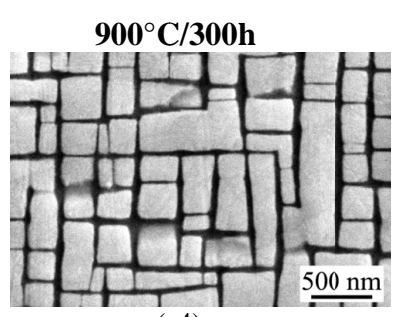

(a4)

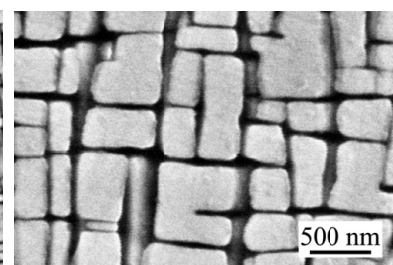

(b4)

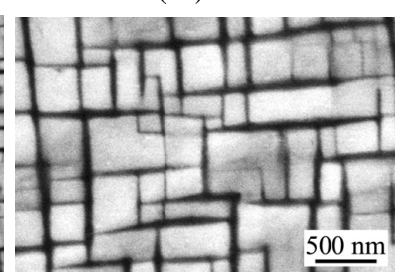

(c4)

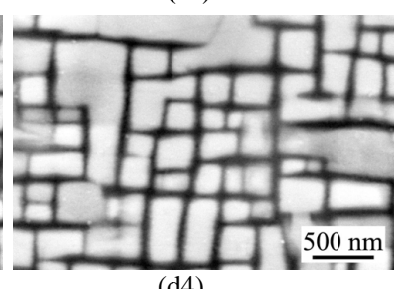

(d4)

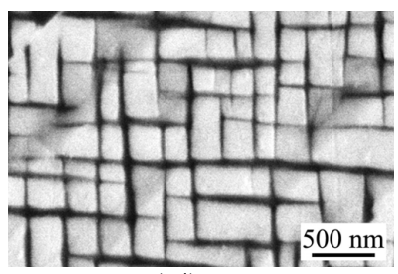

(e4)

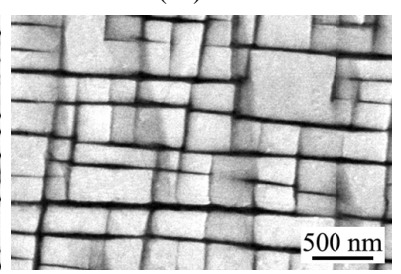

(f4)

Figure 1. Typical microstructure of baseline and quaternary alloys with low levels of alloying additions after solidification and heat treatment at $1300^{\circ} \mathrm{C}$ for $168 \mathrm{~h}$ and then aging treatment at $900^{\circ} \mathrm{C}$ for $50 \sim 300 \mathrm{~h}$, respectively.
(a1) (a4) baseline
(b1) (b4) $2 \mathrm{~V}$
(c1) (c4) $2 \mathrm{Ti}$
(d1) (d4) $2 \mathrm{Mo}$
(e1) (e4) $2 \mathrm{Nb}$
(f1) (f4) $2 \mathrm{Ta}$ 
was observed in the matrix of certain alloys, while some plate-like phases precipitated in 2Mo and 2Nb alloys (images not shown), possibly the $\mathrm{DO}_{19}$ phase based on morphology and composition results. It should be pointed out that the images of $\gamma / \gamma^{\prime}$ microstructure were taken away from these secondary phases. Figures 1 (a3) (f3) are SEM images in the SE mode, showing the typical $\gamma / \gamma^{\prime}$ microstructure in the matrix of six alloys after aging for 50h. The $\gamma^{\prime}$ precipitates were found to be cuboidal in the baseline alloy, as shown in Figure 1(a3). Nearly cuboidal $\gamma^{\prime}$ precipitates were observed in 2V alloy (Figures 1(b3)), and the $\gamma^{\prime}$ phase exhibited cuboidal morphology in 2Ti alloy, shown in Figures (c3). For quaternary alloys containing refractory alloying elements, the $\gamma^{\prime}$ morphology was nearly cubodial in 2Mo alloy (Figure 1(d3)), like that in $2 \mathrm{~V}$ alloy, but it remained cuboidal in $2 \mathrm{Nb}$ and $2 \mathrm{Ta}$ alloys (Figures 1(e3) and (f3)) compared to the baseline alloy. Figures 1(a4) (f4) show $\gamma / \gamma^{\prime}$ two-phase microstructure of these experimental alloys after heat treatment at $900^{\circ} \mathrm{C}$ for $300 \mathrm{~h}$. There was no apparent difference in the $\gamma^{\prime}$ morphology after aging treatment between $50 \mathrm{~h}$ and $300 \mathrm{~h}$ in these experimental alloys, whereas the $\gamma^{\prime}$ size was obviously increased due to coarsening.

Table III summarizes microstructural characteristics of $\gamma^{\prime}$ precipitates in these experimental alloys after aging treatment at $900^{\circ} \mathrm{C}$ for $50 \mathrm{~h}$ and $300 \mathrm{~h}$, including the morphology and volume fraction. It is worthy to note that the volume fractions of the $\gamma$ phase were at very high levels in the range of $74 \%$ to $83 \%$ for all these ternary and quaternary alloys after aging treatment for $50 \mathrm{~h}$. Correspondingly, the results in Table III indicate little change in $\gamma$ morphology and volume fraction in these experimental alloys after long term aging treatment (300h).

Table III. Morphology and volume fraction of $\gamma^{\prime}$ precipitates in ternary and quaternary alloys with low levels of alloying additions after aging heat treatment at $900^{\circ} \mathrm{C}$ for $50 \mathrm{~h}$ and $300 \mathrm{~h}$.

\begin{tabular}{|c|c|c|c|}
\hline \multirow{2}{*}{ Alloy } & $\begin{array}{c}\text { Aging } \\
\text { time, } \mathrm{h}\end{array}$ & $\begin{array}{c}\gamma^{\prime} \text { precipitate } \\
\text { morphology }\end{array}$ & $\begin{array}{c}\gamma^{\prime} \text { volume } \\
\text { fraction, } \%\end{array}$ \\
\hline \multirow{2}{*}{ Baseline } & 50 & cuboidal & 77.3 \\
\cline { 2 - 4 } & 300 & cuboidal & 81.2 \\
\hline \multirow{2}{*}{$2 \mathrm{~V}$} & 50 & nearly cuboidal & 77.9 \\
\cline { 2 - 4 } & 300 & nearly cuboidal & 79.2 \\
\hline \multirow{2}{*}{$2 \mathrm{Ti}$} & 50 & cuboidal & 82.4 \\
\cline { 2 - 4 } & 300 & cuboidal & 76.0 \\
\hline \multirow{2}{*}{$2 \mathrm{Mo}$} & 50 & nearly cuboidal & 74.1 \\
\cline { 2 - 4 } & 300 & nearly cuboidal & 74.4 \\
\hline \multirow{2}{*}{$2 \mathrm{Nb}$} & 50 & cuboidal & 81.2 \\
\cline { 2 - 4 } & 300 & cuboidal & 76.7 \\
\hline \multirow{2}{*}{$2 \mathrm{Ta}$} & 50 & cuboidal & 78.3 \\
\cline { 2 - 4 } & 300 & cuboidal & 80.7 \\
\hline
\end{tabular}

\section{High levels of alloying additions}

Figure 2 presents BSE images, showing the typical microstructure of as-cast and heat-treated baseline alloy and quaternary alloys with 4 at.\% alloying additions. It should be noted that Figures 2(a1) and (a2), taken from the baseline alloy, were again shown here to be convenient for comparison. All as-cast alloys exhibited the dendritic structure, presented in Figures 2(a1) (f1). There was no eutectic structure in the interdendritic regions of the baseline alloy (Figure 2(a1)), but trace amounts of bright-contrast particles and moderate amounts of eutectic pools with dark-contrast were observed in the interdendritic regions of alloys containing $4 \mathrm{~V}$ and 4Ti additions, as shown in Figures 2(b1) and (c1), respectively. Meanwhile, significant amounts of eutectic structure with bright-contrast existed in the interdendritic regions of $4 \mathrm{Mo}, 4 \mathrm{Nb}$ and 4Ta alloys (Figures 2 (d1) (f1)). Composition analyses from EDS results indicate that the bright phases mainly contained refractory alloying elements (W, Mo, Nb and Ta), but the dark-contrast phase in $4 \mathrm{Ti}$ alloy was enriched in $\mathrm{Al}$ and $\mathrm{Ti}$, implying $\beta$ phase. The XRD results identified the bright-contrast phase as $\mu$ phase in $4 \mathrm{Mo}, 4 \mathrm{Nb}$ and $4 \mathrm{Ta}$ alloys (data not shown), whereas no more information was obtained about the dark-contrast phase in $4 \mathrm{Ti}$ alloy.

Figures 2(a2) (f2) show the typical microstructure of secondary phases in the $\gamma$ matrix after as-cast alloys were heat-treated at $1300^{\circ} \mathrm{C}$ for $168 \mathrm{~h}$, exhibiting that the dendritic structure disappeared and the eutectic structure was dissolved. Figure 2(a2) shows trace amounts of the bright-contrast phase $\left(\mathrm{V}_{f}<0.05 \%\right)$ existed in the $\gamma$ matrix of the baseline alloy. For quaternary alloys, there were limited amounts of bright-contrast phases $\left(\mathrm{V}_{f}<2 \%\right)$ in $4 \mathrm{~V}$ and $4 \mathrm{Ti}$ alloys (Figures 2(b2) (c2)), and significant amounts of bright-contrast particles $\left(\mathrm{V}_{f}>7 \%\right)$ in $4 \mathrm{Mo}, 4 \mathrm{Nb}$ and $4 \mathrm{Ta}$ alloys, shown in Figures 2(d2) (f2). The EPMA composition results and volume fraction of these secondary phases at $1300^{\circ} \mathrm{C}$ are listed in Tables IV and V, respectively. Figure 3(a) shows the XRD results of $4 \mathrm{Mo}, 4 \mathrm{Nb}$ and $4 \mathrm{Ta}$ alloys and $\mu$ phase was identified to coexist with $\gamma$ phase in these experimental alloys. Combined with composition results (Table IV), the bright-contrast phases in 4Mo, $4 \mathrm{Nb}$ and $4 \mathrm{Ta}$ alloys were confirmed as the $\mu$ phase, and the bright phases in $4 \mathrm{~V}$ and $4 \mathrm{Ti}$ alloys were presumed as the $\mu$ phase based on EPMA results.

Figures 2 (a3) (f3) and (a4) (f4) show the typical microstructural evolution of secondary phases after thermal exposure at $900^{\circ} \mathrm{C}$ for $50 \mathrm{~h}$ and 300h, respectively. Besides $\gamma$ and $\gamma^{\prime}$ primary phases, the main consideration was taken to examine secondary phases in these experimental alloys, such as the $\mu$ phase inherited from homogenization treatment. For example, Figures 2(a3) (a4) focus on the $\mu$ phase instead of $\gamma / \gamma^{\prime}$ primary phases in the baseline alloy, presenting that the $\mu$ phase was almost unaltered in the baseline alloy after both short and long term aging. Although blocky $\mu$ particles remained unchanged in $4 \mathrm{~V}$ alloy after aging for $50 \mathrm{~h}$ (Figure 2(b3)), they were partially consumed by the plate-like phase with the gray-contrast when the prolonged heat treatment was employed (Figure 2(b4)). The same case occurred in 4Ti alloy under the same aging conditions (Figures 2(c3) (c4)). Figures 2(d3) (f3) and (d4) (f4) present that an obvious solid phase transformation occurred in quaternary alloys containing refractory alloying elements, involving the $\mu$ phase and a new phase with gray-contrast. In $4 \mathrm{Mo}$ alloy, the plate-like phase with gray-contrast precipitated densely in the matrix with the unchanged $\mu$ phase after aging for 50h, as shown in Figure 2(d3). After aging for 300h, besides the plate-like precipitates, some gray precipitates developed through the $\mu$ phase (Figure 2(d4)). In $4 \mathrm{Nb}$ alloy, gray-contrast plate-like precipitates were observed in the matrix, and some blocky precipitates with the same contrast formed surrounding the $\mu$ phase after annealing for 50h (Figure 2(e3)). The density of the plate-like phase increased significantly, and the volume fraction of blocky precipitates was obviously enhanced by consuming the $\mu$ phase after heat treatment for $300 \mathrm{~h}$, shown in Figure 2(e4). In the matrix of 4Ta alloy, there were no plate-like precipitates, but a gray-contrast phase was found to envelop the $\mu$ phase after aging treatment for 50h (Figure 2(f3)). Figure 2(f4) suggests that the phase transformation for increasing the gray phase with decreasing the $\mu$ phase in volume fraction was enhanced after aging for $300 \mathrm{~h}$, and some of the plate-like phase preferentially 
As-cast

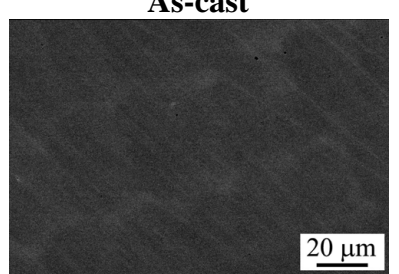

(a1)

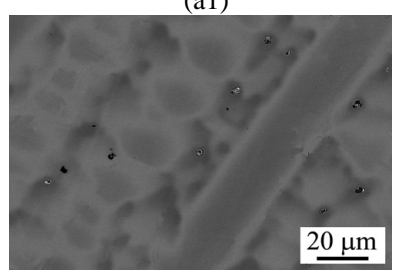

(b1)

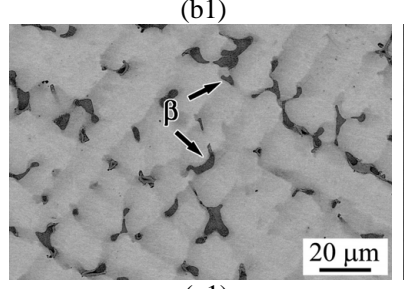

(c1)

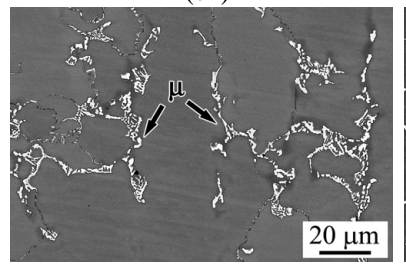

(d1)

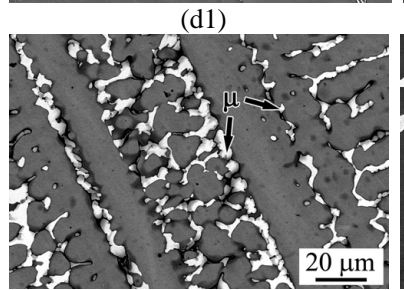

(e1)

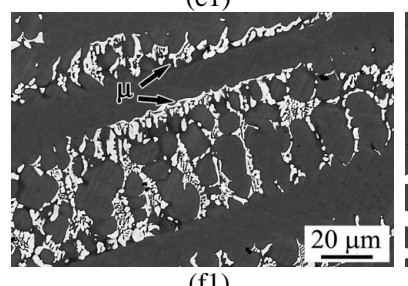

(f1) $1300^{\circ} \mathrm{C} / 168 \mathrm{~h}$

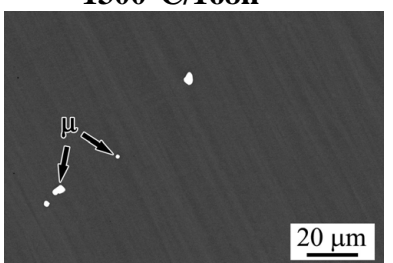

(a2)

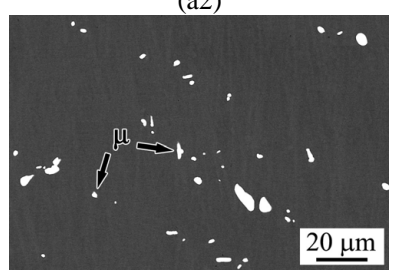

(b2)

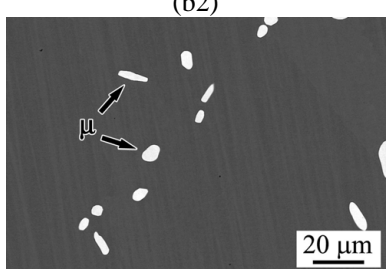

(c2)
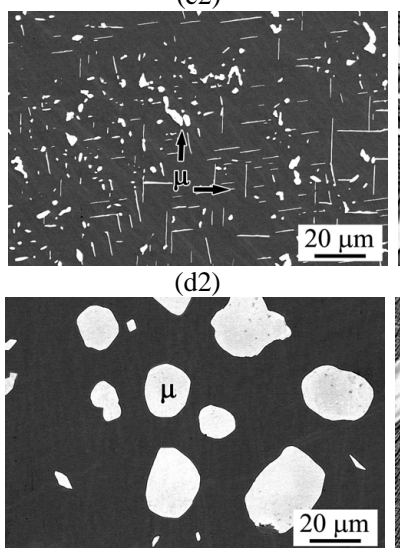

(e2)

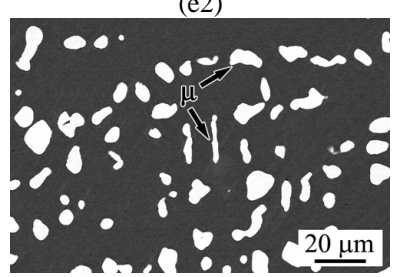

(f2) $900^{\circ} \mathrm{C} / 50 \mathrm{~h}$

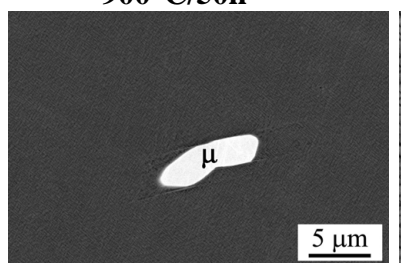

(a3)

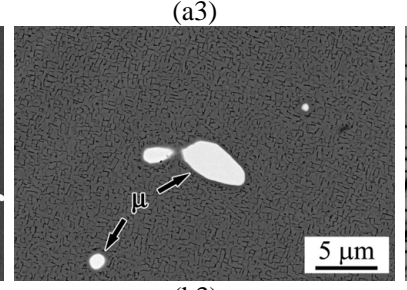

(b3)

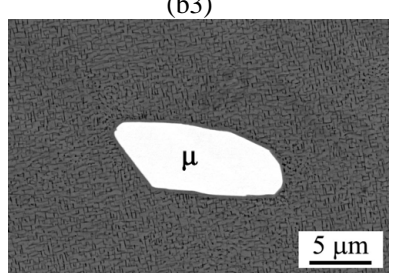

(c3)

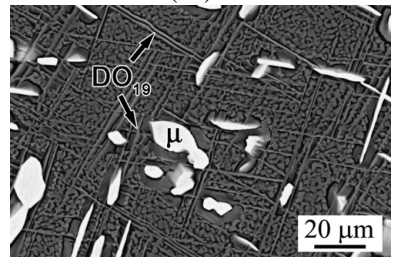

(d3)

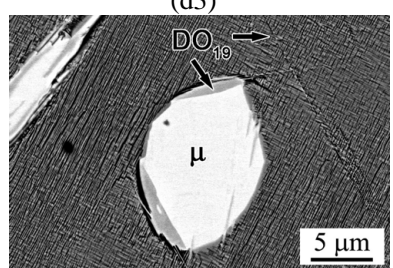

(e3)

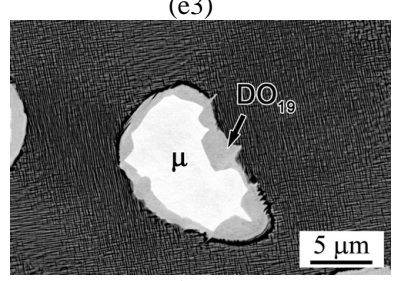

(f3) $900^{\circ} \mathrm{C} / 300 \mathrm{~h}$

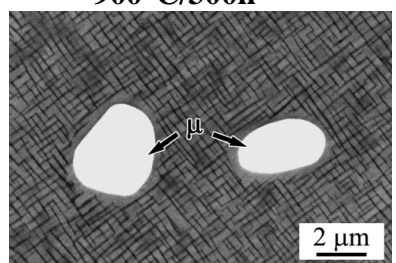

(a4)

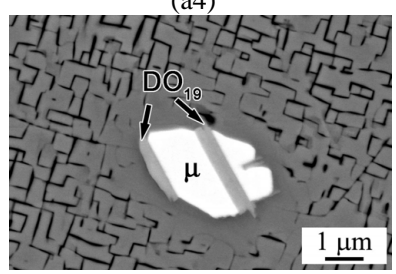

(b4)

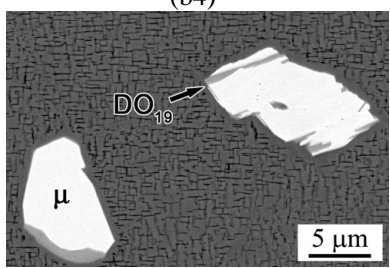

(c4)

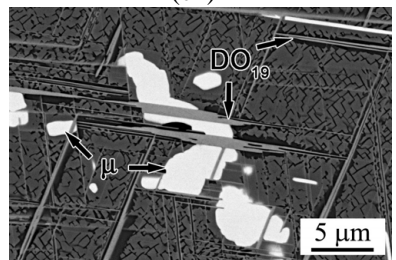

(d4)

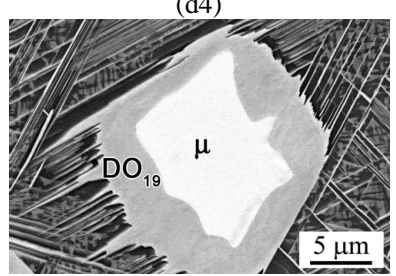

(e4)

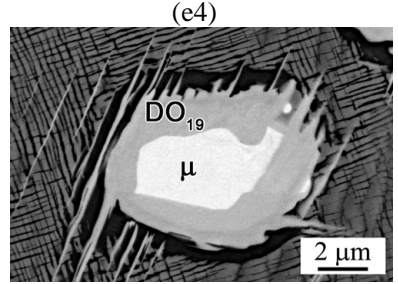

(f4)

Figure 2. Typical microstructure of baseline and quaternary alloys with high levels of alloying additions after solidification and heat treatment at $1300^{\circ} \mathrm{C}$ for $168 \mathrm{~h}$ and then aging treatment at $900^{\circ} \mathrm{C}$ for $50 \sim 300 \mathrm{~h}$, respectively.
(a1) (a4) baseline
(b1) (b4) $4 \mathrm{~V}$
(c1) (c4) $4 \mathrm{Ti}$
(d1) (d4) $4 \mathrm{Mo}$
(e1) (e4) $4 \mathrm{Nb}$
(f1) (f4) $4 \mathrm{Ta}$ 
Table IV. EPMA composition results of the secondary phases in the baseline and quaternary alloys with high levels of alloying additions after heat treatment at $1300^{\circ} \mathrm{C}$ for $168 \mathrm{~h}$ and then aging treatment at $900^{\circ} \mathrm{C}$ for $300 \mathrm{~h}$, respectively, at. $\%$.

\begin{tabular}{|c|c|c|}
\hline \multirow{2}{*}{ Alloy } & $1300^{\circ} \mathrm{C} / 168 \mathrm{~h}$ & $900^{\circ} \mathrm{C} / 300 \mathrm{~h}$ \\
\cline { 2 - 3 } & $\mu$ & $\mathrm{DO}_{19}$ \\
\hline Baseline & Co-2.3Al-40.8W & - \\
\hline $4 \mathrm{~V}$ & Co-1.5Al-39.4W-1.9V & Co-1.5Al-19.0W-2.8V \\
\hline $4 \mathrm{Ti}$ & Co-1.7Al-40.5W-1.5Ti & Co-1.2Al-19.6W-2.4Ti \\
\hline $4 \mathrm{Mo}$ & Co-2.5Al-32.6W-3.6Mo & Co-2.6Al-15.7W-8.6Mo* \\
\hline $4 \mathrm{Nb}$ & Co-3.4Al-18.1W-9.0Nb & Co-0.6Al-14.4W-7.0Nb \\
\hline $4 \mathrm{Ta}$ & Co-2.8Al-18.2W-11.6Ta & Co-0.7Al-14.1W-10.1Ta \\
\hline
\end{tabular}

*EDS composition results

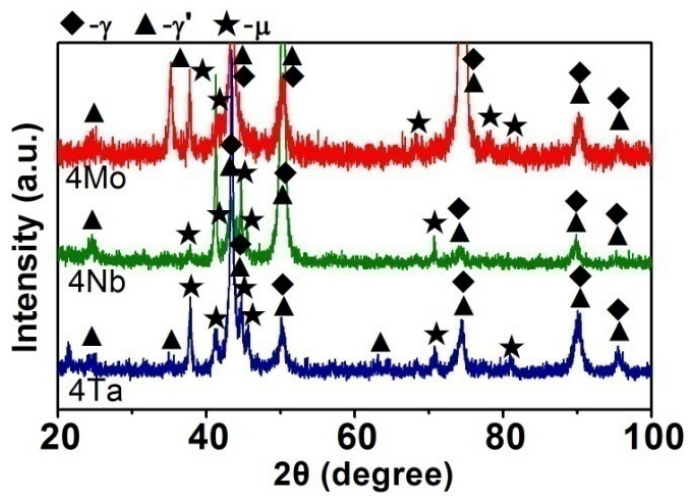

(a)

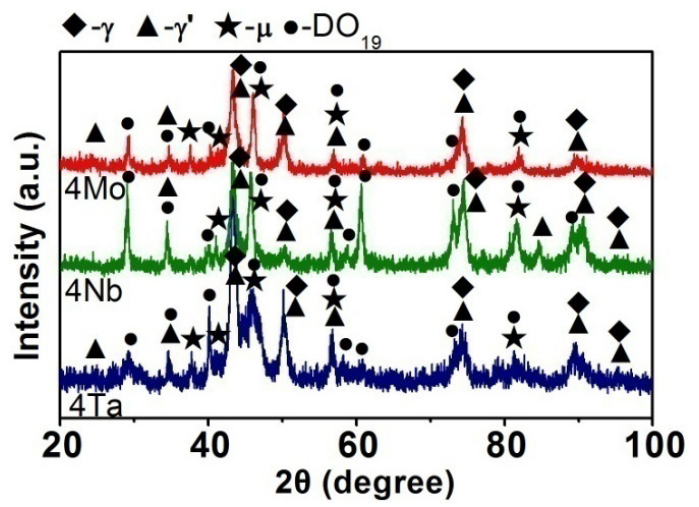

(b)

Figure 3. XRD results of $4 \mathrm{Mo}, 4 \mathrm{Nb}$ and $4 \mathrm{Ta}$ alloys after heat treatment at (a) $1300^{\circ} \mathrm{C}$ for $168 \mathrm{~h}$ and then aging treatment at (b) $900^{\circ} \mathrm{C}$ for $300 \mathrm{~h}$, respectively.

Table V. Volume fraction $\left(\mathrm{V}_{f}\right)$ of $\mu$ phase in experimental alloys after heat treatment at $1300^{\circ} \mathrm{C}$ for $168 \mathrm{~h}, \%$.

\begin{tabular}{|c|c|c|c|c|c|c|}
\hline Alloy & Baseline & $2 \mathrm{~V}$ & $2 \mathrm{Ti}$ & $2 \mathrm{Mo}$ & $2 \mathrm{Nb}$ & $2 \mathrm{Ta}$ \\
\hline $\mathrm{V}_{f}$ & 0.05 & 0 & 0 & 1.6 & 1.6 & 0.8 \\
\hline Alloy & & $4 \mathrm{~V}$ & $4 \mathrm{Ti}$ & $4 \mathrm{Mo}$ & $4 \mathrm{Nb}$ & $4 \mathrm{Ta}$ \\
\hline $\mathrm{V}_{f}$ & & 1.6 & 1.2 & 7.7 & 12.2 & 16.7 \\
\hline
\end{tabular}

precipitated near the $\mu$ phase. It should be noted that all the plate-like precipitates in $4 \mathrm{Mo}, 4 \mathrm{Nb}$ and $4 \mathrm{Ta}$ alloys exhibited evident orientation relationship with the matrix. The composition results of the gray-contrast phase in these experimental alloys after heat treatment at $900^{\circ} \mathrm{C}$ for $300 \mathrm{~h}$ are also listed in Table IV. It is indicated that the gray-contrast phase was enriched in refractory alloying elements ( $\mathrm{W}, \mathrm{Mo}, \mathrm{Nb}$ and $\mathrm{Ta}$ ), but contained lower content of $\mathrm{Al}, \mathrm{V}$ and $\mathrm{Ti}$.

Figure 3(b) shows XRD results of $4 \mathrm{Mo}, 4 \mathrm{Nb}$ and $4 \mathrm{Ta}$ alloys after long term heat treatment at $900^{\circ} \mathrm{C}$. In addition to $\gamma, \gamma^{\prime}$ and $\mu$ phases, peaks of the $\mathrm{DO}_{19}$ phase were identified. Therefore, the gray-contrast phase was the $\mathrm{DO}_{19}$ phase. It is worth noting that diffraction peaks of the $\mu$ phase became weaker compared with those after heat treatment at $1300^{\circ} \mathrm{C}$ (Figure 3(a)). This is in agreement with the microstructural observation that the $\mu$ phase decreased and $\mathrm{DO}_{19}$ phase increased in volume fraction during heat treatment at $900^{\circ} \mathrm{C}$ in $4 \mathrm{Mo}, 4 \mathrm{Nb}$ and $4 \mathrm{Ta}$ alloys (Figure 2).

Transformation temperature

Table VI lists the $\gamma^{\prime}$ solvus, solidus and liquidus temperatures of ternary and quaternary alloys with low levels of alloying additions after heat treatment at $1300^{\circ} \mathrm{C}$ and then aging treatment at $900^{\circ} \mathrm{C}$ for $50 \mathrm{~h}$. In order to determine the $\gamma^{\prime}$ solvus temperatures more accurately, aged alloys were employed instead of as-cast ones. It was $1029^{\circ} \mathrm{C}$ in the baseline alloy. The addition of $2 \mathrm{~V}$ decreased the $\gamma^{\prime}$ solvus temperature by $32^{\circ} \mathrm{C}$, but $2 \mathrm{Ti}$ addition increased it by $36^{\circ} \mathrm{C}$. A slight negative influence of $2 \mathrm{Mo}$ addition was presented on $\gamma^{\prime}$ solvus temperature, while $2 \mathrm{Nb}$ addition promoted the thermal stability of the $\gamma^{\prime}$ phase by about $20^{\circ} \mathrm{C}$. It is inconsistent with some reports that $\gamma^{\prime}$ solvus temperature was increased by $\mathrm{V}$ and Mo additions [6, 8], possibly resulting from the composition deviation or different baseline alloy. Among all these alloying elements, Ta addition showed the most positive effect on $\gamma^{\prime}$ solvus temperature, which was $1100^{\circ} \mathrm{C}$ for $2 \mathrm{Ta}$ alloy. Compared with the baseline alloy, the solidus temperatures were decreased in some extent by the additions of alloying elements, and $\mathrm{Ti}$ and $\mathrm{Nb}$ additions showed the most negative effect on the solidus temperatures. The baseline alloy exhibited the highest liquidus temperature at $1476^{\circ} \mathrm{C}$, but it was decreased in some extent under various alloying additions.

Table VI. $\gamma^{\prime}$ solvus, solidus and liquidus temperatures of the baseline and quaternary alloys with low levels of alloying additions after heat treatment at $1300^{\circ} \mathrm{C}$ and then aging treatment at $900^{\circ} \mathrm{C}$ for $50 \mathrm{~h},{ }^{\circ} \mathrm{C}$.

\begin{tabular}{|c|c|c|c|}
\hline Alloy & $\gamma^{\prime}$ solvus & Solidus & Liquidus \\
\hline Baseline & 1029 & 1459 & 1476 \\
\hline $2 \mathrm{~V}$ & 997 & 1443 & 1472 \\
\hline $2 \mathrm{Ti}$ & 1065 & 1408 & 1468 \\
\hline $2 \mathrm{Mo}$ & 1018 & 1440 & 1468 \\
\hline $2 \mathrm{Nb}$ & 1047 & 1405 & 1464 \\
\hline $2 \mathrm{Ta}$ & 1100 & 1412 & 1455 \\
\hline
\end{tabular}




\section{Discussion}

In order to achieve desired high-temperature properties under extremely severe conditions, more than ten alloying elements were introduced during continuous alloy development of advanced multi-component superalloys [1, 9]. In addition to $\gamma / \gamma^{\prime}$ phases, however, complex chemical compositions might lead to possible existence of secondary phases, which generally decreased microstructural stability and mechanical behavior of superalloys. Thus, the relationship of alloy chemistry and microstructure is of primary importance to assure an optimum combination of properties. In the current study, Co-Al-W-base quaternary alloys were investigated to understand phase equilibia and microstructure with various alloying additions.

Phase equilibria at $1300^{\circ} \mathrm{C}$ and $900^{\circ} \mathrm{C}$

In the Co-rich corner of Co-Al and Co-W binary systems at $1300^{\circ} \mathrm{C}$, $\gamma$ phase coexists with CoAl-base $\beta$ phase and $\mathrm{Co}_{7} \mathrm{~W}_{6}$-base $\mu$ phase, respectively [11]. Previous studies reported that alloys containing high levels of $\mathrm{W}$ content exhibited $\mu$ precipitates in the matrix of Co-Al-W ternary system at $1200^{\circ} \mathrm{C}$ and $1300^{\circ} \mathrm{C}[12,13,15]$. The baseline alloy in the current study contained trace amounts of the $\mu$ phase $\left(\mathrm{V}_{f} \sim 0.05 \%\right)$ and thus can be regarded as $\gamma$ single-phase alloy after heat treatment at $1300^{\circ} \mathrm{C} .2 \mathrm{~V}$ and $2 \mathrm{Ti}$ additions showed no influence on the precipitation of secondary phases, but high levels of them introduced small amounts of the $\mu$ phase $\left(\mathrm{V}_{f}<2 \%\right)$ in the matrix of $4 \mathrm{~V}$ and $4 \mathrm{Ti}$ alloys. For refractory alloying elements (Mo, $\mathrm{Nb}$ and $\mathrm{Ta}$ ), low levels of alloying additions resulted in the formation of the $\mu$ phase with the similar limited levels $\left(\mathrm{V}_{f}<2 \%\right)$, and high levels of alloying additions (4 at.\%) strongly affected the precipitation of the $\mu$ phase with large volume fraction $\left(\mathrm{V}_{f}>7 \%\right)$. It can be summarized that the quaternary alloys with negligible amounts of the $\mu$ phase, namely $2 \mathrm{~V}, 4 \mathrm{~V}, 2 \mathrm{Ti}, 4 \mathrm{Ti}, 2 \mathrm{Mo}, 2 \mathrm{Nb}$ and 2Ta alloys, were considered to be $\gamma$ single phase alloys, and alloys with high levels of refractory alloying elements $(4 \mathrm{Mo}, 4 \mathrm{Nb}$ and 4Ta alloys) were clearly in the $\gamma+\mu$ two-phase field at $1300^{\circ} \mathrm{C}$.

According to phase equilibria at $900^{\circ} \mathrm{C}$, although the equilibrium phase field of the $\gamma^{\prime}$ phase did not exist in binary systems, new compound $\gamma^{\prime}-\mathrm{Co}_{3}(\mathrm{Al}, \mathrm{W})$ formed in Co-Al-W ternary system [2]. In the current study, the $\gamma / \gamma^{\prime}$ two-phase microstructure was observed in all experimental alloys after heat treatment at $900^{\circ} \mathrm{C}$ for $300 \mathrm{~h}$, coupled with the $\mu$ phase and/or the $\mathrm{DO}_{19}$ phase in certain alloys, respectively. The $\mu$ phase appeared to be not thermodynamically stable at $900^{\circ} \mathrm{C}$ referring to the isothermal section in the Co-rich corner of Co-Al-W ternary system at $900^{\circ} \mathrm{C}$ [2]. It inherited from the precipitation at $1300^{\circ} \mathrm{C}$ and gradually transformed into the $\mathrm{DO}_{19}$ phase due to slow diffusion of refractory alloying elements. Different from the unequilibrated $\mu$ phase, the $\mathrm{DO}_{19}$ phase is stable and probably presented when the content of $\mathrm{W}$ is relatively high, since the $\gamma / \gamma^{\prime}$ two-phase field was very narrow [2]. The current microstructural observation indicated that $\mathrm{DO}_{19}$ phase did not existed in the baseline alloy, and only high levels of $\mathrm{V}$ and $\mathrm{Ti}$ additions resulted in the negligible amounts of the $\mathrm{DO}_{19}$ phase. However, 2Mo and $2 \mathrm{Nb}$ additions promoted the formation of plate-like $\mathrm{DO}_{19}$ phase in the matrix, and high levels of refractory alloying additions played an effective role in increasing the volume fraction of $\mathrm{DO}_{19}$ precipitates. Therefore, the $\gamma / \gamma^{\prime}$ two-phase region located in $2 \mathrm{~V}, 4 \mathrm{~V}, 2 \mathrm{Ti}, 4 \mathrm{Ti}$ and $2 \mathrm{Ta}$ alloys at $900^{\circ} \mathrm{C}$, while $\gamma+\gamma^{\prime}+\mathrm{DO}_{19}$ three phases were stable in $2 \mathrm{Mo}, 2 \mathrm{Nb}, 4 \mathrm{Mo}, 4 \mathrm{Nb}$ and 4Ta alloys. Based on the current results, it is indicated that non-refractory alloying elements possessed limited influence on the phase equlibria, but refractory alloying additions strongly affected phase constituents in Co-Al-W-base alloys.

The phase equilibria in experimental alloys at $1300^{\circ} \mathrm{C}$ and $900^{\circ} \mathrm{C}$ are summarized in Table VII. Unlike non-refractory alloying elements $(\mathrm{V}$ and $\mathrm{Ti})$, the present study suggests that refractory alloying additions (Mo, Nb and $\mathrm{Ta}$ ) strongly influenced the thermodynamics of Co-Al-W-base alloys by promoting the formation of $\mu$ and $\mathrm{DO}_{19}$ phases. It is also revealed that current alloying elements did not exhibit positive effects on enlarging the $\gamma+\gamma^{\prime}$ two-phase region like Ni [7]. The additions of refractory alloying elements must be carefully optimized in order to generate $\gamma / \gamma^{\prime}$ two-phase alloys and avoid the possible precipitation of $\mu$ and $\mathrm{DO}_{19}$ phases. On the other hand, recently, Kobayashi et al suggested that the $\gamma^{\prime}$ phase was metastable at $900^{\circ} \mathrm{C}$ and $\gamma, \beta$ and $\mathrm{DO}_{19}$ phases were thermodynamically in equilibrium using diffusion couple experiments [12]. Therefore, more investigation is necessary to find effective alloying additions to enlarge $\gamma / \gamma^{\prime}$ two-phase region and provide reliable database of phase equlibria for further developing Co-Al-W-base alloys.

Table VII. Phase equilibria in experimental alloys at $1300^{\circ} \mathrm{C}$ and then aging treatment at $900^{\circ} \mathrm{C}$, respectively.

\begin{tabular}{|c|c|c|}
\hline Alloy & $1300^{\circ} \mathrm{C}$ & $900^{\circ} \mathrm{C}$ \\
\hline Baseline & $\gamma^{*}$ & $\gamma^{+} \gamma^{\prime * *}$ \\
\hline $2 \mathrm{~V}$ & $\gamma$ & $\gamma^{+} \gamma^{\prime}$ \\
\hline $2 \mathrm{Ti}$ & $\gamma$ & $\gamma^{+} \gamma^{\prime}$ \\
\hline $2 \mathrm{Mo}$ & $\gamma^{*}$ & $\gamma+\gamma^{\prime}+\mathrm{DO}_{19} * *$ \\
\hline $2 \mathrm{Nb}$ & $\gamma^{*}$ & $\gamma+\gamma^{\prime}+\mathrm{DO}_{19}^{* *}$ \\
\hline $2 \mathrm{Ta}$ & $\gamma^{*}$ & $\gamma^{*} \gamma^{\prime * *}$ \\
\hline $4 \mathrm{~V}$ & $\gamma^{*}$ & $\gamma+\gamma^{\prime * *}$ \\
\hline $4 \mathrm{Ti}$ & $\gamma+\mu$ & $\gamma+\gamma^{\prime * *}$ \\
\hline $4 \mathrm{Mo}$ & $\gamma+\mu$ & $\gamma+\gamma^{\prime}+\mathrm{DO}_{19}{ }^{* *}$ \\
\hline $4 \mathrm{Nb}$ & $\gamma+\mu$ & $\gamma+\gamma^{\prime}+\mathrm{DO}_{19}{ }^{* *}$ \\
\hline $4 \mathrm{Ta}$ & &
\end{tabular}

* including trace amounts of the $\mu$ phase

** including the metastable $\mu$ phase

\section{Volume fraction and morphology of $\gamma^{\prime}$ phase}

It is well known that $\gamma^{\prime}$ phase is the primary strengthening phase for alloys containing $\gamma+\gamma^{\prime}$ two-phase microstructure, like Ni-base superalloys. Their creep resistance mainly depends on the volume fraction of $\gamma^{\prime}$ precipitates. In the present work, the $\gamma^{\prime}$ volume fraction in the baseline alloy was $77.3 \%$, and it remained at very high levels in the range of $74 \%$ to $83 \%$ under various alloying additions after thermal exposure at $900^{\circ} \mathrm{C}$ for $300 \mathrm{~h}$ without the appearance of $\gamma^{\prime}$ rafting (Figure 1 and Table III). Although previous studies indicated that $\gamma^{\prime}$ volume fraction was increased with $\mathrm{Ti}, \mathrm{Nb}$, $\mathrm{Ta}$ and $\mathrm{V}$ additions but decreased with Mo addition [6, 8], no obvious influence of alloying additions on $\gamma^{\prime}$ volume fraction was observed in the current quaternary alloys, compared to the baseline alloy with such a high level of $\gamma^{\prime}$ volume fraction. On the other hand, it was reported that the longest creep life occurred when the volume fraction of $\gamma^{\prime}$ phase was in the range of $65 \%$ to $70 \%$ in both $900^{\circ} \mathrm{C} / 392 \mathrm{MPa}$ and $1100^{\circ} \mathrm{C} / 137 \mathrm{MPa}$ in Ni-base single crystal superalloys [16]. In contrast, the appropriate $\gamma^{\prime}$ volume fraction for superior creep properties of Co-Al-W-base alloys has not been reported, but Titus et al revealed that alloys containing a high $\gamma^{\prime}$ volume fraction exhibited better creep properties compared with 
alloys with low volume fraction of $\gamma^{\prime}$ precipitates at $900^{\circ} \mathrm{C} / 241 \sim$ $310 \mathrm{MPa}$ [17].

It is well accepted that creep resistance was also affected by $\gamma / \gamma^{\prime}$ lattice misfit, which has its close relationship with $\gamma^{\prime}$ morphology, especially in Ni-base single crystal superalloys $[1,9]$. Previous investigation indicated that spherical $\gamma^{\prime}$ precipitates resulted from a near zero misfit, while the cuboidal morphology of $\gamma^{\prime}$ phase correlated with lattice misfit deviated from zero [18]. It was reported that the temperature capability of Ni-base single crystal superalloys was improved by changing the lattice misfit towards more negative [19]. Recent investigation indicated that Co-Al-W-base alloys with cuboidal $\gamma^{\prime}$ precipitates had the comparable creep rate to Ni-base superalloy IN713C at $850^{\circ} \mathrm{C}$ and single-crystal alloy René $\mathrm{N} 4$ at $900^{\circ} \mathrm{C}[6,17]$. In this study, the $\gamma^{\prime}$ morphology in the baseline alloy was cuboidal, and no apparent influence was observed by alloying additions except the nearly cuboidal $\gamma^{\prime}$ phase in $2 \mathrm{~V}$ and 2Mo alloys. These results show good agreement with $\gamma^{\prime}$ morphology reported by previous studies [2-6, $13,20]$. To date, among limited creep studies in Co-Al-W-base superalloys, the effects of lattice misfit and some other factors (such as $\gamma^{\prime}$ size and alloy chemistry) on creep resistance of Co-Al-W-base alloys have not been investigated yet. Therefore, more investigation is required to understand their creep resistance and behavior for further practical applications of Co-Al-W-base alloys.

\section{Precipitation and composition of $\mu$ phase}

In addition to the effective strengthening phases in the matrix and/or grain boundaries like $\gamma^{\prime}$ phase and carbides, it is possible to promote the formation of undesirable secondary phases during heat treatment or more commonly during service as alloying additions exceed the solubility of the $\gamma$ matrix, among which TCP phases are most notable $[1,9]$. $\mu$ phase is one common type of TCP phases and generally precipitated due to excessive content of $\mathrm{Cr}$ and refractory alloying elements $[1,9]$. In the current study, it precipitated at $1300^{\circ} \mathrm{C}$ as an equilibrium phase coexisting with $\gamma$ phase. Trace amounts of $\mu$ phase were observed in the baseline alloy and limited amounts of this phase existed in $4 \mathrm{~V}, 4 \mathrm{Ti}, 2 \mathrm{Mo}, 2 \mathrm{Nb}$ and $2 \mathrm{Ta}$ alloys, while large amounts of $\mu$ phase were present under high levels of refractory additions. Its morphology was blocky. The composition results indicated that the $\mu$ phase was evidently enriched in $\mathrm{W}, \mathrm{Mo}$, $\mathrm{Nb}$ and $\mathrm{Ta}$, but depleted in $\mathrm{Al}, \mathrm{V}$ and $\mathrm{Ti}$. Although the $\mu$ phase existed at $900^{\circ} \mathrm{C}$ in the early stage, it inherited from the precipitation at $1300^{\circ} \mathrm{C}$ and was considered to be a metastable phase. As the aging time was extended, the volume fraction of $\mu$ phase gradually decreased (Figures 2 and 3 ) due to lower diffusion coefficients of refractory elements and it would ultimately disappear.

The current results also suggest that refractory alloying elements promoted the formation of the $\mu$ phase, and high levels of them strongly increased the volume fraction of $\mu$ phase. Although no study has been reported for the effect of $\mu$ phase on high temperature mechanical properties of Co-Al-W-base superalloys, the composition results of the $\mu$ phase suggest that it absorbed refractory alloying elements from the matrix and thus would be detrimental to high temperature performance. Therefore, in practice, the contents of refractory alloying elements need to be carefully balanced to avoid the formation of $\mu$ phase.

\section{Precipitation and morphology of $\mathrm{DO}_{19}$ phase}

Like $\mu$ phase, the $\mathrm{Co}_{3} \mathrm{~W}$-based $\mathrm{DO}_{19}$ phase is derived from Co-W binary system and expected to precipitate in the matrix with high levels of $\mathrm{W}$ content in Co-Al-W ternary system [2]. Present research showed two types of $\mathrm{DO}_{19}$ precipitates in morphology, plate-like and blocky shape. The plate-like $\mathrm{DO}_{19}$ phase precipitated as a result of the decomposition of $\gamma$ matrix at $900^{\circ} \mathrm{C}$, and their preferentially orientation should be similar to that in previous studied Co-20W alloy, resulting from a (0001) habit plane complying with the orientation relationship: $(0001)_{\mathrm{hcp}} / /(111)_{\mathrm{fcc}}$, $[11 \overline{2} 0]_{\mathrm{hcp}} / /[1 \overline{1} 0]_{\mathrm{fcc}}[21]$. In contrast, the blocky $\mathrm{DO}_{19}$ precipitates were transformed from the $\mu$ phase by consuming refractory alloying elements, since the composition difference between the $\mu$ and $\mathrm{DO}_{19}$ phases corresponded to normal downhill diffusion process (Table IV). Based on these results, it is indicated that refractory alloying elements strongly promoted the precipitation of the $\mathrm{DO}_{19}$ phase. The effect of $\mathrm{DO}_{19}$ phase on high temperature mechanical properties has not been investigated in Co-Al-W-base superalloys yet. However, its plate-like morphology and high levels of refractory alloying elements content implied the deleterious effect on mechanical behavior. According to the present results, it is suggested that refractory alloying elements must be carefully controlled to prevent the formation of $\mathrm{DO}_{19}$ phase for an optimum microstructure and mechanical proprieties.

\section{Conclusions}

The influence of non-refractory alloying elements $(\mathrm{V}$ and $\mathrm{Ti})$ and refractory alloying elements (Mo, $\mathrm{Nb}$ and $\mathrm{Ta}$ ) on high-temperature phase equilibria, $\gamma^{\prime}$ phase and secondary phases as well as transformation temperatures were investigated in the current study. The following conclusions can be drawn:

1. High levels of refractory alloying elements (4 at.\%) strongly promoted the formation of $\mu$ phase at $1300^{\circ} \mathrm{C}$. These quaternary alloys were located in $\gamma+\mu$ two-phase equilibrium region, while the other alloys were considered to be $\gamma$ single-phase alloys with negligible amounts of the $\mu$ phase. The $\mu$ phase contained high levels of $\mathrm{W}, \mathrm{Mo}, \mathrm{Nb}$ and Ta, but was depleted in $\mathrm{Al}, \mathrm{V}$ and $\mathrm{Ti}$.

2. The $\gamma / \gamma^{\prime}$ two-phase microstructure was generated in all experimental alloys containing low levels of alloying additions ( 2 at.\%) after aging at $900^{\circ} \mathrm{C}$, and the volume fractions of the $\gamma^{\prime}$ phase were at very high levels in the range of $74 \%$ to $83 \%$. Compared with the baseline alloy, alloying additions did not show strong effects on $\gamma^{\prime}$ morphology, which remained cuboidal or nearly cuboidal after long term aging.

3. For quaternary alloys with refractory alloying additions after aging at $900^{\circ} \mathrm{C}$ except $2 \mathrm{Ta}$ alloy, the $\mathrm{DO}_{19}$ phase precipitated in addition to $\gamma$ and $\gamma^{\prime}$ phases, as well as the blocky $\mu$ phase, which inherited from the precipitation at $1300^{\circ} \mathrm{C}$. The $\gamma+\gamma^{\prime}+\mathrm{DO}_{19}$ equilibrium phase field was located in $2 \mathrm{Mo}, 2 \mathrm{Nb}$, $4 \mathrm{Mo}, 4 \mathrm{Nb}$ and $4 \mathrm{Ta}$ alloys. And the $\gamma / \gamma^{\prime}$ two-phase microstructure existed with negligible amounts of the $\mathrm{DO}_{19}$ phase in $2 \mathrm{~V}, 2 \mathrm{Ti}$, 2Ta, $4 \mathrm{Ti}$ and $4 \mathrm{~V}$ alloys.

4. There were two types of morphology of $\mathrm{DO}_{19}$ phase: one was plate-like and precipitated in the matrix; the other was blocky 
morphology and transformed from the previous $\mu$ phase. It is suggested that refractory alloying additions (Mo, Nb and Ta) promoted the phase transformation for $\mathrm{DO}_{19}$ phase.

5. Compared with the baseline alloy, Ta, $\mathrm{Ti}$ and $\mathrm{Nb}$ additions showed stronger effect on promoting $\gamma^{\prime}$ phase stability by increasing $\gamma^{\prime}$ solvus temperature in the order: $\mathrm{Ta}>\mathrm{Ti}>\mathrm{Nb}$, while $\mathrm{V}$ and Mo additions presented negative effect on $\gamma^{\prime}$ solvus temperature.

\section{Acknowledgments}

The authors would like to acknowledge useful discussions with Y.R. Zheng. The financial support provided by the National Natural Science Foundation of China (Grant No.: 50771012), Aviation Science Foundation of China (Grant No.: 2009ZF74) and New Century Excellent Talents in University, Chinese Ministry of Education (Grant No.: NCET-06-0079) are gratefully acknowledged.

\section{References}

1. C.T. Sims, N.S. Stoloff and W.C. Hagel, Superalloys II (New York, NY: Wiley, 1987).

2. J. Sato, et al., "Cobalt-Base High-Temperature Alloys", Science, 312 (5770) (2006), 90-91.

3. A. Suzuki, G.C. DeNolf and T.M. Pollock, "Flow Stress Anomalies in $\gamma / \gamma^{\prime}$ Two-Phase Co-Al-W-Base Alloys", Scripta Materialia, 56 (5) (2007), 385-388.

4. A. Suzuki and T.M. Pollock, "High-Temperature Strength and Deformation of $\gamma / \gamma^{\prime}$ Two-Phase Co-Al-W-Base Alloys", Acta Materialia, 56 (6) (2008), 1288-1297.

5. T.M. Pollock, et al., "New Co-Based $\gamma-\gamma$ ' High-Temperature Alloys", JOM, 62 (1) (2010), 58-63.

6. A. Bauer, et al., "Microstructure and Creep Strength of Different $\gamma / \gamma^{\prime}$-Strengthened Co-Base Superalloy Variants", Scripta Materialia, 63 (12) (2010), 1197-1200.

7. K. Shinagawa, et al., "Phase Equilibria and Microstructure on $\gamma$ ' Phase in Co-Ni-Al-W System", Materials Transactions, 49 (6) (2008), 1474-1479.

8. M. Ooshima, et al., "Effects of Quaternary Alloying Elements on the $\gamma^{\prime}$ Solvus Temperature of Co-Al-W Based Alloys with FCC/L1 $1_{2}$ Two-Phase Microstructures", Journal of Alloys and Compounds, 508 (1) (2010), 71-78.

9. R.C. Reed, The Superalloys: Fundamentals and Applications (New York: Cambridge University Press, 2006).

10. F. Xue, Z.Q. Li and Q. Feng, "Mo Effect on the Microstructure in Co-Al-W-Based Superalloys", Materials Science Forum, 654-656 (2010), 420-423.
11. T.B. Massalski, et al., ed. ASM Handbook, vol. 3 (Metals Park, OH: American Society for Metals, 1990).

12. S. Kobayashi, et al., "Determination of Phase Equilibria in the Co-rich Co-Al-W Ternary System with a Diffusion-Couple Technique", Intermetallics, 17 (12) (2009), 1085-1089.

13. X.H. Li, et al., "Heat-Treated Microstructure of Co-Al-W Ternary Alloys", Journal of University of Science and Technology Beijing, 30 (12) (2008), 1369-1373.

14. F. Xue, M.L. Wang and Q. Feng, "Phase Equilibria in Co-Rich Co-Al-W Alloys at $1300^{\circ} \mathrm{C}$ and $900^{\circ} \mathrm{C}$ ", Materials Science Forum, 686 (2011), 388-391.

15. S. Miura, K. Ohkubo and T. Mohri, "Mechanical Properties of Co-Based $\mathrm{L}_{2}$ Intermetallic Compound $\mathrm{Co}_{3}(\mathrm{Al}, \mathrm{W}) "$, Materials Transactions, 48 (9) (2007), 2403-2408.

16. T. Murakumo, et al., "Creep Behaviour of Ni-Base Single-Crystal Superalloys with Various $\gamma^{\prime}$ Volume Fraction", Acta Materialia, 52 (12) (2004), 3737-3744.

17. M.S. Titus, A. Suzuki and T.M. Pollock, "Creep and Directional Coarsening in Single Crystals of New $\gamma-\gamma$ ' Cobalt-Base Alloys", Scripta Materialia, 66 (8) (2012), 574-577.

18. M. Fährmann, et al., "Influence of Coherency Stress on Microstructural Evolution in Model Ni-Al-Mo Alloys", Acta Metallurgica et Materialia, 43 (3) (1995), 1007-1022.

19. H. Harada and H. Murakami, "Design of Ni-base Superalloys", Computational Materials Design ed. T. Saito (Berlin, NY: Springer-Verlag, 1999), 53-55.

20. K. Shinagawa, et al., "Ductility Enhancement by Boron Addition in Co-Al-W High-Temperature Alloys", Scripta Materialia, 61 (6) (2009), 612-615.

21. P.A. Carvalho, et al., "On the Fcc--> $\mathrm{D}_{19}$ Transformation in Co-W Alloys", Acta Materialia, 50 (18) (2002), 4511-4526. 